\title{
The 'Ideal' vs. 'Real' Values Educator: How teachers' Practice Impacts on Values Education at a Disadvantaged South African School
}

\author{
Drake, ML \\ Faculty of Education, University of Fort Hare \\ mdrake@ufh.ac.za
}

Doi:10.5901/mjss.2014.v5n20p1542

\begin{abstract}
A renewed emphasis on values education provides a 'beacon of hope' as to how South Africans may find common ground and become a united society through education. Teachers are described as role-models in the process of values realisations, with competence and commitment being key ingredients in how teachers model new South African values. This study investigates the role of the teacher in values education, by comparing policy ideals and context realities. Functioning in difficult circumstances, disadvantaged (township) schools continually struggle against the odds. Using qualitative research methods situated in the interpretive paradigm, observations, in-depth interviews and focus groups with teachers reveal deeply explanatory evidence that support how the attitudes and behaviours of teachers severely impact values realisation and enactment in a school community. Findings indicate that policy-makers need to carefully consider the end-users of policy; the teachers in the field. Without targeted interventions to address these ground-level, contextual issues, values policies will remain an idealistic rhetoric.
\end{abstract}

Keywords: values education, township schools, policy-practice gap, teachers' practice, South African education

\section{Introduction}

The policy-practice gap has been widely debated, especially in South African education which saw an influx of new policies after apartheid in the early 1990s. Much of this literature attempts to explain how difficult it is to implement idealistic policy that is intended to change the practice of education 'on the ground' (Jansen, 2002; Sayed, 2002). This article presents a study that interrogates the relationship between the idealistic South African values policies regarding teachers practice and the contexts in which they are to manifest; South African schools. This article forms part of a deeper research project that explored values education in a disadvantaged, township primary school in Mdantsane, East London, South Africa. The particular focus is on the role of the teacher in the transmission of values. Ground-level reasons why this policy-practice gap occurs are analysed.

Values education has been clearly placed as a vehicle of change and a vital component of South African schooling. Many policy documents, presented briefly in diagrammatic form in Figure I, address the crucial role of the teacher in the values realisation process. For example, the Manifesto on values, education and democracy (Department of Education, 2001) describes teachers as role-models and stresses competence and commitment as key ingredients in effective modelling of values. Yet studies suggest that South African schools are in crisis (Department of Education, 2010b; Eastern Cape Department of Education, 2009-2010; Lemon, 2004). Although the theoretical debates around values education are crucial in establishing a platform for understanding the role of values in schooling, the author proposes that explanatory evidence reporting at a grass-roots level what the current state of values education is, is also important to support the theory. Questions such as, "What are teachers currently doing to impact on the realisation and enactment of values in their schools?' are seldom reported on.

The conceptual positioning of the article begins by exploring the South African school context (township schools), the literature on values education, and the role of the teacher, both 'idealistic' and 'realistic', in the values realisation process. The significance of this article remains a description of ground level practice; a 'bottom-up' approach, describing how teachers' practice impacts on values realisation and enactment in a township primary school.

\section{Review of Literature}

Township residential areas in South Africa were established during apartheid as racially segregated, low-cost housing developments for black labourers. Aspects of poverty, crime, violence, abuse and unsafe environments have become 
associated with township communities, at times described as 'war zones' (Mampane \& Bouwer, 2011, p. 114). Most cities and towns in South Africa have a township community that borders, and is associated with, it. Schools in these black settlement areas are generally attended by black students and taught by black teachers (Moloi, 2010). Context-specific challenges in these schools include increasing levels of poverty among school communities, high levels of illiteracy and unemployment, high parent mortality rates that link to the number of child-headed families that are disadvantaged, and illresourced schools. These schools operate without libraries, computers, electricity and running water, described as, "difficult schooling context[s]" (2010, p. 623). Many township schools suffer from acute shortages of textbooks and learning materials (Ngcobo \& Tikly, 2010). Bloch (2008) explained how many rural and township schools are described as 'sinkholes', where learners end up being 'warehoused' rather than being educated.

These context realities naturally affect the nature of teachers' work in township schools. Jansen (2001) describes powerful images of teachers after apartheid, including the teacher as 'liberator', 'facilitator', and 'performer'. Together with these images, education policy reform that encourages more active, reflective and participant classrooms places much emphasis on the role of the teacher in post-apartheid South Africa. However, for many teachers, their training and experience lies within the country's apartheid history, where educators were described as 'obedient civil servant[s] that executed the well-defined instructional tasks per an official syllabus and a "moderated" examination' (Jansen, 2001, p. 243). This mismatch in history, training and new policy expectations create a tense and demanding environment for teachers, especially when situated in township communities.

South Africa has a large stake in the ground regarding the importance of values education in schools. The start of the South African values education initiative is briefly illustrated in Figure I.

The initial six report values (Department of Education, 2000) were framed by the South African Constitution, resulting in the ten Manifesto values (Department of Education, 2001). In addition to the ten values, sixteen educational strategies are prescribed, which in theory, should shape how these values are taught in schools. The second of the sixteen strategies suggested in the Manifesto is role-modelling; teachers are expected to play a foundational part of values enactment and realisation. One of the most significant ways children acquire values is to see individuals they admire and respect exemplify those values in their attitudes and in the way they behave (Department of Education, 2001). Teachers are therefore leaders in values education, and set the example since children learn by example, consciously and unconsciously. The two crucial aspects of role-modelling for teachers were described as commitment and competence. Teachers are required, by policy, to be committed to and competent in their roles as educators. Values have since filtered into most education policies.

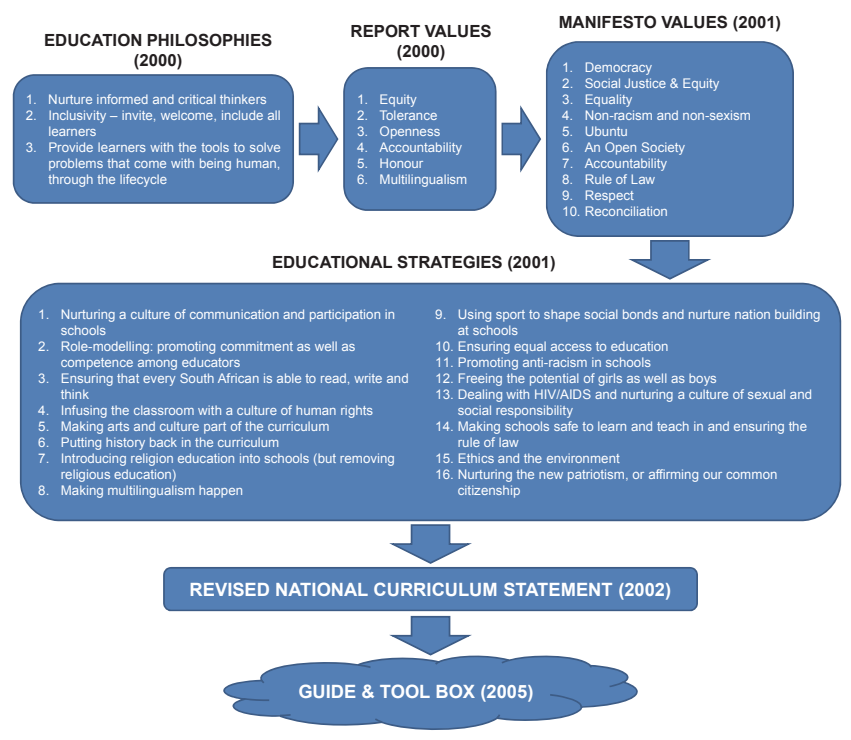

Figure I: Diagrammatical representation of the start of the values initiative in South Africa.

International research tends to support teachers and schools as important participants in the moral and ethical 
development of children, but this is not without (Hill, 2000; Snook, 2007; Veugelers \& Vedder, 2003; Winton, 2010). Within South African values policies regarding role-modelling, competence and commitment are addressed as fundamental elements in the modelling process. It commits teachers to (Code of Conduct, South African Council of Educators as cited in Department of Education, 2001, p. 21):

- acknowledge the noble calling of their profession to educate and train the learners of their country

- acknowledge that the attitude, dedication, self-discipline, ideals, training and conduct of the teaching profession determine the quality of education

- acknowledge, uphold and promote basic human rights

- commit themselves to do all within their power, in the exercising of their professional duties, to act in accordance with the ideals of their profession

- act in a proper and becoming way such that their behaviour does not bring the teaching profession into disrepute

- In other words, to have internalised the ten fundamental values of the South African Constitution themselves, and to act as role models for their students.

These requirements are framed by competence; teachers should be qualified and demonstrate competence in accordance to the seven roles articulated in the Minimum standards for Teacher education qualifications (Department of Education, 2010a), as well as the acknowledgement that competence without commitment and dedication is meaningless. However, there has been considerable critical debate on South Africa's idealistic values documents and the role of the teacher. Pendlebury and Enslin (2007, p. 252) contend that the practical principles of the Manifesto may be elusive for the many teachers trained in an authoritarian and non-expansive tradition, and under severe pressure from constant demands of ever-changing policy. The more extensive and hands-on guide (Department of Education, 2005) published in 2005 appears to recognise the difficulty teachers face with values and human rights education. It provides a detailed interpretation of how to use these principles. Yet, it also adds to the intensification of teachers' work. With the already considerable demands from educational policy, it simply is not reasonable to expect engagement with the Manifesto strategies or extensive guide (Pendlebury \& Enslin, 2007).

Another contribution to the debates involving values initiative was made by Green (2004, p. 112), who addresses the lack of acknowledgement regarding the influence of context and the personal positions of teachers themselves. This may be influenced by the different modes of educator training or levels of educator's confidence which need to be considered. If teachers are to take on the responsibility of values education, they need to be encouraged to engage in a form of conversation about values and associated virtues in their school or community. Teachers need to address their own deeper understanding of their personal values and the processes and relationships between them. Assumptions that teachers understand, appreciate or realise values personally or within their teaching practice cannot be made (Green, 2004). Teacher participants in a South African values study (du Preez \& Roux, 2010) showed that there are discrepancies between values taught at schools, and those which are nurtured at home and in the community. Teachers felt that learners were taught human rights values in schools, but when they were outside of school, they faced a very different set of values. This creates a complex scenario for teachers in South African schools, particularly township school teachers who work in challenging and difficult environments.

The intention of this study was to investigate how teacher's practice, particularly their commitment and competence, shaped the realisation and enactment of the Manifesto values in a township school setting. The theoretical and philosophical underpinnings of values education (Halstead \& Pike, 2006; Kohlberg, 1981; Noddings, 2005; Piaget, 1932; Ryle, 1972) were considered. Solomons and Fataar (2011) recommended that South Africans "advance the view that a commitment to values education in schools, alert to the requirements for building a shared understanding about which values might be best fostered in classrooms, informed by an appreciation of how values may be properly taught at the different levels of the schools system, remains the key to generating a questioning and productive citizenry in South Africa" (p. 231). Hence, the purpose of this research is summarised below.

\section{Purpose of Research}

This article addresses the complex relationship between values education policy ideals and context realities regarding the role of the teacher in South African township schools. Literature suggests that the ground level realities that township schools and teachers face are extremely difficult, yet values education policies frame teachers as role models, exemplars and instructors of these values. This study aims to investigate the role of the teacher in the teaching and learning of values, by revealing descriptive evidence regarding the current state of values education at a typical South African 
school. Simply put, the article attempts to answer the question: How do teachers impact on the values realisation and enactment process in a township school setting?

\section{Research Processes and Approach}

This study is set within the interpretive paradigm (Bassey, 1999). Interpretivists explain action by interpreting what they observe and collect, retrieving the meanings embedded within the evidence (Robinson, 1993). In this orientation, any attempt to understand social reality must proceed from, but not be confined to, people's understanding of their own reality (Strelitz, 2005). The sample was chosen purposively (Maxwell, 2005) due to the nature of this research in a township environment. Elements of access, safety (Lee, 1995) and school effectiveness were considered in order to render an effective research process. This primary school, in the Mdantsane township schooled 990 learners. There were 26 teachers at the school, and classes were occupied by 70 plus learners. Facilities were poor, including poor ablution facilities, lack of textbooks and teaching and learning resources as well as socio-economic factors such as poverty and HIVIAIDS.

The methodological approach of this study is situated in a generic qualitative study (Merriam, 1988). Values education may be better understood by the personal 'human' factor of researching the teachers of a township school, and understanding what teachers do or do not do in order for values to be realised and enacted. Therefore, not only the physical events and behaviours that took place at the school were of importance, but also how the teachers made sense of these, and how or whether their understanding of the specific South African values influenced their behaviour (Maxwell, 2005, p. 22). Soon into the fieldwork, it was discovered that the teachers at this township primary school, were unaware of any of the South African values or the values education strategies that were meant to be implemented in their school. All participants answered 'no' when asked if they knew what the Manifesto on values, education and democracy was about. Yet, values were being realised and enacted, without the guidelines or suggestions from policy. Detailed observations (Maxwell, 2005), in-depth, semi-structured interviews (Yin, 2003) and focus groups (Cohen \& Manion, 2000) were used as qualitative evidence gathering tools over the six month evidence collection period. The evidence was collected in a three phase cycle over a six month period, as illustrated in Figure II.

Observation occurred daily for a period of 3 months. All aspects of school life were observed, from assemblies, staff meetings, teaching and learning in the classroom, after-school activities and parent-teacher meetings to meetings in the principal's office and staff in the staffroom. This evidence was recorded daily in thick text formats. Document analysis was planned, but did not materialise due to a lack of documents. This evidence provided a foundation for the creation and direction of interview and focus group questions. Focus groups were held with groups of teachers and with groups of learners. Groups of 5 participants were brought together to mutually discuss the evidence that was presented. Any responses that did not make sense were asked in different ways, and to different groups. These focus groups were recorded, transcribed and inserted into MS word files. This evidence was used to shape Phase 3 of the fieldwork. Individual in-depth, semi-structured interviews were used to probe deeper. These interviews were also recorded, transcribed and inserted into MS word files.

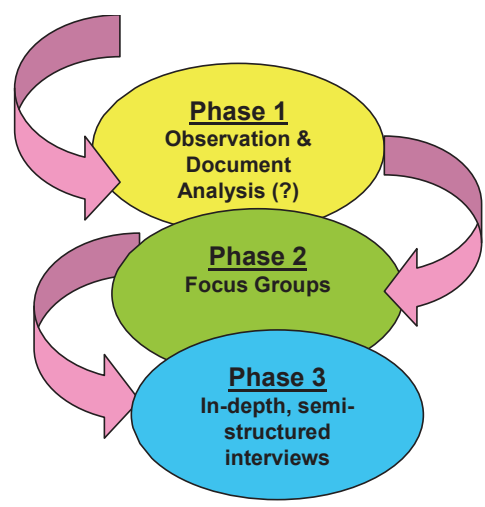

Figure II: Fieldwork Phases used to collect evidence 


\section{Ethical Considerations}

Research processes and the collection of evidence can impose something unnatural on the natural contextual situation. Hence it is important that when commencing fieldwork, researchers do so in a way as to minimize harm or suffering to participants (Blake, 2007). The following considerations were made:

\subsection{Establishment of a cultural contact}

Understanding the role of the teacher in values education required an understanding of reality as perceived and acted by the teacher participants themselves (Morrison, 2002). One of the primary means of addressing this complexity was through the establishment of a 'cultural contact' who knew and understood this school and its environment. This contact was approached as a culturally and socially relevant point of reference should the participants have any concerns. This person was used as a point of 'neutrality' to ensure that information was recorded fairly and that the school community's position was objectively noted. This person read and commented on all observation notes and signed a confidentiality contract.

\subsection{Consent and confidentiality}

Another ethical concern in qualitative research involving humans is that involvement must be voluntary and participants should be informed truthfully of the nature of the research (Snook, 2000). These points were explicitly explained in the information sheets and consent forms given to all participants. Participants were able to withdraw from the study at any point.

\subsection{Member-checks}

Part of the methodological process in this study was member-checks (Cohen, Manion, \& Morrison, 2000) which allowed the teachers to respond to the evidence to ensure dependability (Thomas, 2006). Transcripts of focus groups, interviews and observation notes were made available to participants at any stage during the six month fieldwork period.

\subsection{Trustworthiness, validity, credibility}

Yin $(2003$, p. 10) encourages every case study investigator to work hard to report all evidence fairly. One of the most important ways that fairness was addressed was through the process of disconfirmation. Robinson and Lai (2006) explain how acknowledging you are wrong, when assumptions and conclusions are mistaken, is a vital step in improving validity. They also emphasise that findings should be expressed with tentativeness and open-mindedness, since the possibility for mistakes is always present. A bias that limits validity is confirmation bias. Therefore, disconfirmation was a methodological technique used to address trustworthiness and credibility (Lincoln \& Guba, 1985). Disconfirmation is described simply as the tendency to give more weight to data and data sources that confirm rather than disconfirm your prior assumptions and hypothesis (Robinson \& Lai, 2006, p. 59). The researcher therefore, paid particular attention to those things that did not match up or make sense in light of the evidence collected. Special attention was paid to evidence that 'stood out' from the rest. This will be further detailed in the presentation of the evidence. Another trustworthiness technique involved using current literature and studies to situate the findings of this study. Similar findings that resonated with the evidence were drawn upon for credibility and trustworthiness.

\section{Analysis of the Evidence}

The analysis process began informally after the first day of fieldwork. Creswell (2002) calls this 'preliminary exploratory analysis', which means that the researcher obtains a general sense of the data, makes notes of ideas, thinks about the organisation of the data and considers whether more data are needed in particular areas of interest. This process needed to be adopted, as it shaped what needed to be done next during the fieldwork phase, for example, what was observed was then used to create interview and focus group questions. Data analysis under general inductive analysis (Thomas, 2006) was carried out through multiple readings and interpretations of the raw data (observation notes, focus group transcripts and interview transcripts), the inductive component. It followed three distinctive processes (Thomas, 2006, p. 238): 
1. To condense extensive and varied raw text data into a brief, summary format. This was established through many readings of the evidence. Themes emerged and this allowed the evidence to be condensed into a summary format under 'teachers' practice' headings. This process was called, Description of Events (what teachers were doing), and emerged directly from observation evidence.

2. To establish clear links between the research objectives and the summary findings derived from the raw data and to ensure that these links are both transparent and defensible. This was achieved by addressing the research intentions in light of the observed events. Links and tensions became evident. The result from this process was explanations from the teachers themselves and how justifiable they were in light of other raw data and education policy. This process was called, Explanations from Participants (what teachers were saying), and emerged from the focus groups and interview material.

3. To develop a model or theory about the underlying structure of experiences or processes that are evident in the data. These overarching themes revealed a model or theory on the most prominent ways in which values were or were not being communicated and enacted in this school. This process was called, Evaluation (conclusions drawn), and relied on South African values education policy, as well as other literature and findings that resonated with this evidence.

\section{Presentation of Evidence}

\subsection{Description of events}

Fieldwork material is used to illustrate teacher realities in this school as observed during fieldwork. These themes related to 'teachers' practice' (what teachers do) and were the first step in understanding how teachers were involved in the realisation and enactment of values.

\subsubsection{Absenteeism of teachers}

Absenteeism is a growing problem in township schools in South Africa (Alston, 2006, March 15). The following accounts are a few examples of the many instances that this behaviour was recorded:

The department of education officials raised the fact that during the month of June, 70 percent of staff attended school.

Therefore, 30 percent were absent during this month [Observation Notes (ON)].

Many teachers were not present at school or at the meeting [ON].

Principal ... You know, and this absenteeism of teachers is so very high here. Teachers do not come to school [Individual Interview (II)].

A teacher stated that no learning would happen today because of casual day [school uniform not worn]. He said they give up as the learners do no work and they talk during class [ON].

Teacher ... There is no point in even trying to teach because of the strike. [II].

Absenteeism was a crucial teachers' behaviour that impacted on the values realisation and enactment process at the school.

\subsubsection{Lateness}

Promptness, or lack thereof, proved to be an issue affecting the school's day-to-day functioning. Although this school had bells notifying staff and learners of lesson changes, break times and end of school times, there were several occasions where lateness appeared to be deeply embedded in the organisational culture of this school. The accounts below highlight a few of the many occasions where lateness was observed in the fieldwork material:

The teacher who arrived fifteen minutes late for the class, shouted at the learners who arrived after her. [ON].

Teachers were arriving at school half an hour after the school bell rang [ON]). 
The principal and teachers were in the staff room and were arriving well after the school bell rang. The principal herself was late, and she immediately announced to the staff that everyone needs to improve their punctuality, herself included $[O N])$.

This morning there was a teacher monitoring the late comers and writing down their names. There were as many late teachers as there were learners [ON].

Lateness was an organisational behaviour that did not correlate with the values policy requirements.

\title{
7.1.3 Disengagement
}

On several occasions during the fieldwork, behaviour was observed that suggested discrepancies between how teachers are described in South African educational policy and what happens in reality.

The class was unsettled and disruptive when the teacher left for the staffroom, and although there were still fifteen minutes left of the lesson, the male mathematics teacher did not return [ON].

The teacher sat throughout the lesson while texting on her mobile telephone [ON].

Learner 1 ... Teachers don't come to class, especially after the long break ... after lunch because they are always talking or doing whatever ... [Focus Group (FG)].

Learner 2 ... The teachers did not do anything [extra-curricular/sport] this year. Maybe they will start it next year [FG].

Teachers appeared to actively disengage from their roles and responsibilities at school.

\subsubsection{Discipline}

This was an extremely sensitive topic to investigate throughout the fieldwork. Yet, in an attempt to understand the impact teachers have on the values realisation process, this evidence needed to be revealed and discussed. Corporal punishment is nothing new in current education literature in South Africa, although The Constitution of South Africa states that everyone has the right not to be treated or punished in a cruel, inhumane or degrading way (Liebenberg, 2010, p. 495). Yet, Naong (2007) stresses that evidence is constantly resurfacing that teachers are not complying with the legislation regarding corporal punishment in South Africa.

\begin{abstract}
When the next teacher came in a bit later, she asked for the stick. She did not bash it on the desks and blackboard (as was observed previously) but poked and hit children who misbehaved with it (ON).
\end{abstract}

The following lesson observed was a Xhosa lesson. This teacher pinched two learners who were misbehaving. Immediately afterwards, the teacher reported on the pressures she had as a teacher at the school (ON).

The learner physically cowered away from the male teacher, who reprimanded him aggressively after he laughed with another boy sitting next to him (ON).

The female teachers made two learners come to the front of the class, where she beat their hands with a stick (ON). The teacher was trying to walk in between the learners' desks, and at one stage he hit one of the learners who was not copying from the blackboard. All the learners were extremely obedient after this (ON).

These everyday practices of the teachers at this school shaped the values realisations and enactments that occurred. Teachers' behaviours of lateness, absenteeism, disengagement and discipline did not align with the policy stipulations of teachers requirements in the values initiative and did not reflect the 10 Manifesto values. This evidence shaped the interview and focus group phase of the evidence collection process.

\subsection{Explanations from participants}

Interestingly, the teachers' initial response (what teachers say) to questions asked in the focus groups and interviews contradicted the observation evidence. Teachers first spoke of being dedicated, motivated and effective educators. 
However, when actual observation evidence was presented to them, the teachers had alibis and rationalisations as to why this behaviour occurred and why it was acceptable, in their view:

Teacher 2 ...To me, even this taking on of learners with disabilities, it is a challenge and not all of us have been trained to deal with them. And even when we are given kids that do not belong here, we are expected to be giving and producing miracles with these children ... and the numbers of other learners in the classrooms makes it very difficult [FG].

Teacher 4 ... we were not trained with these new ways of teaching [FG].

Teacher 1 ... because sometimes you get out of the class because you are called to the office or something [FG].

Teacher 3 ... A contributing factor that does not go down well with us is that here at school we have large classes, and then when you sit down and think I am teaching a learning area [Life Orientation] and I'm teaching over 300 learners, I have to make sure that over 300 files are up to date, and then you teach another learning area and you think I have to make sure that all those files are up to date, so you are dealing with close to 700 files and you are dealing with all this on your own, you have to teach all these classes... And then you are still a class teacher with all this paperwork. I catch up on this work sometimes... [FG].

Teacher 5 ... And when you look at it, the schools in town, they have small numbers, they have administration support like secretaries and clerks and things... There is somebody who does this job, for this paperwork but here we are expected to do it. It must come from us, and it is not fair... [FG].

Teacher ... There are many ways of punishing learners, but you find that even those [new] methods, they are ineffective. For instance, some learners enjoy staying outside. If you chase a learner outside, they will play out there and be happy. Or then the teacher has denied the right of learning in class, because you have sent the child out ... Hit the child with a stick, but with love. Discipline is a big problem that needs to be debated again and needs more discussion and the review of that legislation [II].

Teachers had many reasons and rationalisations as to why they were absent, late, disengaged and why they used physical strategies to discipline the learners in their classes. These teacher behaviours severely contradicted new South African values and their strategies for implementation. Before the article addresses discussion around these findings, evidence that 'stood out' during the disconfirmation process (Robinson \& Lai, 2006) is presented.

\subsection{Evidence that 'stood out'}

As described in the research process section of this paper, disconfirmation was used to address trustworthiness and credibility (Lincoln \& Guba, 1985). Through the process of data analysis, there was a small amount of evidence that supported effective role-modelling, effective teaching and motivated teachers. Although this group of teachers were a minority (six out of 23 teachers), it is important that these notes be presented and discussed in light of this study. Fieldwork notes showed the following examples:

The Grade 7 Mathematics lesson was engaging for the learners (group work, discussions). The teaching was effective, and the learners were attentive [ON].

This teacher gave reassuring touches on the shoulders of the learners, and encouraged them to do well in this formal assessment project [ON].

Teacher ... I look forward to coming to school, to seeing these kids, to helping them learn. That is my job. I don't want to get promotion to HOD because that is administration. I want to be making a difference in the classroom [II].

Learner 1 ... because of my teacher. The one teacher, they comfort me, they look after me. They help me to get a better education. When I think of this teacher, I think of my parents [FG].

Learner 2 ... Our teacher is well educated and give us a lot of information. My favourite teacher, it is like they have a library in their head. Our teacher knows everything. It is really like they have a library in his head [FG].

This standing out section is important as it highlights teachers who have a positive impact on values enactment 
and realisation through modelling competence and commitment in their behaviours. This small group of motivated teachers, although not aware of the values education initiative, still adhere to effective professional practice and model values that align with those in policy. These two set of evidence, while extremely distinctive, reveal interesting disjunctions in the values realisation process at schools. These dilemmas are discussed below.

\section{Evaluation and Discussion of Findings}

South African values policies place the teacher as a vital component in the realisation and learning process of values. The Values Manifesto lays out a role modelling strategy that promotes commitment as well as competence among teachers. The findings presented thus far highlight the vast disjunction between the 'ideal' and the 'real' teacher. When teachers are late for school, when they are disengaged in their professional practice, when they do not arrive for school, or they infringe on the human rights of the learners in their classrooms by resorting to physical discipline, they violate the values that policy describes as crucial for South African society. They also create an environment that promotes values in direct contrast to the Manifesto and Constitutional values. In an attempt to evaluate these findings through policy and similar studies, commitment and competence will be addressed as the key ingredients for role modelling in values enactment and realisation success.

\subsection{Commitment}

Commitment amongst teachers was discussed in the opening sections of this paper as a key ingredient to effective rolemodelling and values realisation in South African schools. The evidence shows that the behaviours of the majority of teachers does not reflect 'commitment' as described in policy. Commitment can also be viewed as motivation; "teacher motivation encompasses a teacher's desire to participate in the teaching and learning processes within a school setting. It is the basis for a teacher's involvement or non-involvement in academic and other activities at school (Ofoegbu, 2004). Because of the disparity between the small group of effective teachers and the majority of teachers, the underlying questions concerning this evidence are: What is motivating or (de) motivating these teachers? Why is this behaviour tolerated and accepted in the school community? The reasons expressed by participants are not credible, especially when there is a small group of motivated teachers in the same position as them behaving in very different ways. When comments from the two groups are compared, it becomes clear that the 'excuses and reasons' are the reality for all these teachers, but some choose another path when facing the challenges of class size, training, inclusion and work load. One way to begin analysing these behaviours is through the discourse of teacher motivation. Teachers are crucial in the moulding, shaping and teaching of values in schools. But this is considered part of teachers' work, and does not manifest in additional monetary or other reward. The drastic strike action and go-slows for remuneration increases in South Africa create at times a volatile and destructive atmosphere in school life. Remuneration issues are a continual area of contest in South Africa. Yet, the small group of effective teachers prove that it may be more multi-faceted than merely an issue of money.

Instrumental reasons for teaching like salary, status, the desire to urbanise and the attainment of qualifications is often identified by educators. Others view teaching as an avenue of service, a noble profession to which one is called (Jessop \& Penny, 1998, p. 396). Teachers from the minority group in this study spoke fondly of their intentions (personal motivators) in becoming teachers with statements such as "wanting to make a difference", "changing the lives of children" and "working with children" [Individual Interviews, Teachers]. Six teachers modelled behaviour that was committed and motivated and hence had a positive impact on values realisations and enactments. Promises of redress in 1994 assured South Africans that an influx of money into township schools would see them on par with other schools. This is far from being achieved. It may be argued that new policies, especially those addressing abstract concepts like values, are formulated for more successful schools. These new policies are not context specific, which means that they do not address the unique environments of disadvantaged township schools.

In order for policies to be context specific, the first consideration needs to be end users; teachers. "Teacher-asperson" (Jessop \& Penny, 1998, p. 401) needs to inform policy-makers and teacher development if education change is to be sustained. They suggest that a shift from theorising about educational change, from the arena of policy to the arena of teacher beliefs and their histories, is necessary: "The recovery of teacher voice and vision becomes critical" (p.402). Role modelling as an 'ideal' strategy for values education appears to be ineffective in this township school context, because policy formation does not consider 'where teachers are at' in this specific environment. Abstract conceptualisation and understanding of values and values education does not meet the complex and challenging environment these teachers face daily. Hence, the behaviours of disengagement, lateness, absenteeism and physical 
discipline continue to distort South African values and at times, model the direct opposite of these policy ideals.

\subsection{Competence}

Teacher competence remains a challenge in the South African context. Harley, Brasa, Bertram, Mattson and Pillay (2000, p. 288) emphasise how the demands on teachers' skills and professionalism are considerable, especially for teachers working in impoverished schools. An aspect that dramatically affects the demands on teachers' skills and professionalism is educational change, for example, the values education initiative. Teachers are continually faced with the task of facilitating and implementing education reform that was designed without involving them (Swanepoel, 2008, p. 39). The evidence showed that teachers were completely unaware of values education policies or guides. Reform is more than merely an implementation of policy issue. It relies on basic pedagogical skill, understanding and knowledge that for many of these teachers are not being developed, facilitated and supported. They are unable to see the benefit of change or acquiring skills to implement change. Hargreaves (1994, p. 43) describes this as the 'real crunch'; merging policy, development and the teacher-as-person. The relationship between these new programs or policies, and the thousands of subjective realities embedded in people's individual and organisational contexts and their personal histories, is vital. The result of the lack of this "real crunch" is poor communication, leaving schools and teachers unaware, fearful and helpless in light of change. Hence, competence, a requirement of all teachers as prescribed in values strategies, becomes an avenue of resentment and failure and severely impacts the values realisation process.

Teachers also need, to a degree, to 'unlearn' past practices, such as a reliance on physical means of discipline. Significant change, whether voluntary or imposed, entails an 'unlearning' of what is believed to be right, and this brings about a sense of loss, anxiety and struggle (Harley et al., 2000, p. 300). For South African teachers, nostalgia for the old order was coupled with suspicion towards the new, politically radical values that accompanied the collapse of apartheid and the coming of modernity. Teachers also found difficulty in reconciling the contradictions of the breakdown in traditional values, seen as a bad thing, and the collapse of apartheid, seen as a good thing. These teachers often reflected on the past as a time that was good, orderly and effective [Focus Group, Teachers]. They articulate only negative aspects of today's school environments, and continually complain about indiscipline, lack of parental involvement and lack of leadership. When complex change is involved, like the incorporation of values education into teachers' work, people do not, and cannot, change by being told to do so (Fullan, 1993, p. 24). Policy must marry with teachers' histories and beliefs. "If policy makers in South Africa propose successful education policy change, it is essential to elicit the underlying assumptions, experiences, social and historic context, the degree to which, these are congruent or not with teachers' beliefs, experiences, commitments and educational practices" (Smit, 2001, p. 81).

\section{Conclusion}

Commitment and competency are described as the ingredients for teacher role modelling and teaching values. These two qualities go hand-in-hand. Teachers are more likely to be committed when they feel more competent in what they do in the classroom and school. Understanding policy, implementing policy, and having the specific skills to cope with 'new' educational thought are crucial. These findings suggest that when these teachers are more competent in the understanding and skills needed for the requirements of new policy, they are likely to feel more committed and motivated in their role. Role modelling as a strategy for values education requires teachers to 'go the extra mile', and without commitment and competence, this is not achievable. 'Teacher-as-person' and context-specific consideration in policy to invoke commitment and motivation in teacher's behaviour and development seems crucial if policy is to drive change. Unique histories and backgrounds need to be considered. Idealistic policy written for effective or successful schools has minimal impact on this disadvantaged school context. Until then, the current state of 'values education' in schools such as these will create a vast disjunct between policy and reality and the distance between the 'ideal' and the 'real' teacher will continue to undermine effective educational practice.

\section{Acknowledgement}

I would like to thank Professor Viviane Robinson and Professor Robin Small from the University of Auckland, New Zealand for their invaluable contributions during this study. 


\section{References}

Alston, K. (2006, March 15). There are too many reports of teacher absenteeism and of non-teaching when they are at school. Daily Dispatch Online, Retrieved August 20, 2009, from http://www.dispatch.co.zal

Bassey, M. (1999). Case study research in educational settings: Doing qualitative research in educational settings. Buckingham: Open University Press.

Blake, M. (2007). Formality and friendship: Research ethics review and participatory action research. ACME: An international E-journal for critical Geographies, 6(3), 411-421.

Bloch, G. (2008). The complexity of systems change in education. In S. Maile (Ed.), Education and poverty reduction strategies: Issues of policy coherence (colloquium proceedings). Cape Town: Human Sciences Research Council.

Cohen, L., \& Manion, L. (2000). Research methods in education (4th ed.). London: Routledge.

Cohen, L., Manion, L., \& Morrison, K. (2000). Research methods in education (5th ed.). London: RoutledgeFalmer.

Creswell, J. W. (2002). Educational research: Planning, conducting, and evaluating quantitative and qualitative research. Upper Saddle River, NJ: Merrill.

Department of Education. (2000). Report of the working group on values in education. Retrieved April 20, 2008, from http://www.info.gov. za/otherdocs/2000/education.htm

Department of Education. (2001). Manifesto on values, education and democracy. Retrieved February 28, 2008, from http://www.info. gov.za/view/DownloadFileAction?id=70295

Department of Education. (2005). Values and human rights in the curriculum: A guide. Retrieved July 11, 2011, from http://www.hrea.org/index.php?base_id=104\&erc_doc_id=4920

Department of Education. (2010a). Draft policy on Minimum requirements for teacher education qualifications from the HEQF. Retrieved May 1, 2014 from http://www.dhet.gov.za/Reports\%20Doc\%20Library/Draft\%20Policy\%20on\%20minimum\%20requirements \%20for\%20Qualifications\%20in\%20Education.pdf.

Department of Education. (2010b). Education statistics in South Africa 2009. Retrieved August 5, 2011, from http://www.education. gov.za/LinkClick.aspx?fileticket=p3PuRJ8\%2F5VQ\%3D\&tabid=93\&mid=1131

du Preez, P., \& Roux, C. (2010). Human rights values or cultural values? Pursuing values to maintain positive discipline in mulitcultural schools. South African Journal of Education, 30(1), 13-26. Retrieved May 16, 2011, from http://www.ajol.info/index.php /saje/article/viewFile/52599/41205

Eastern Cape Department of Education. (2009-2010). Annual Report. Retrieved 3 August 2011 from http://www.ecdoe.gov.za /files/documents/Annual-Report-2009-2010.pdf.

Fullan, M. (1993). Change forces: Probing the depths of educational reform. London: Falmer.

Green, L. (2004). Nurturing democratic virtues: Educators' perspectives. South African Journal of Education, 24(2), 108-113. Retrieved January 15, 2011, from http://www.ajol.info/index.php/saje/article/viewFile/24974/20658

Halstead, J., \& Pike, M. (2006). Citizenship and moral education: Values in action. London: Routledge.

Hargreaves, A. (1994). Changing teachers, changing times: Teachers' work and culture in the postmodern age. London: Cassell.

Harley, K., Brasa, F., Bertram, C., Mattson, E., \& Pillay, S. (2000). "The real and the ideal": Teacher roles and competences in South African policy and practice. International Journal of Educational Development, 20(2000), 287-304. Retrieved December 12, 2010, from http://www.sciencedirect.com.ezproxy.auckland.ac.nz/science/article/pii/S0738059399000796

Hill, B. (2000). Can state schools teach values? End-games in public education. Delta, 52(1), 27-44.

Jansen, J. (2001). Image-ining teachers: Policy images and teacher identity in South African classrooms. South African Journal of Education, 21(4), 242-246. Retrieved July 6, 2011, from http://137.215.9.22/bitstream/handle /2263/876/Jansen\%20 (2001)e.pdf? sequence $=2$

Jansen, J. (2002). Political symbolism as policy craft: Explaining non-reform in South African education after apartheid. Journal of Education Policy, 17(2), 199-215. Retrieved October 7, 2011, from http://www.tandfonline.com.ezproxy.auckland.ac.nz /doi/pdf/10.1080/02680930110116534

Jessop, T., \& Penny, A. (1998). A study of teacher voice and vision in the narratives of rural South African and Gambian primary school teachers. International Journal of Educational Development, 18(5), 393-403. Retrieved July 10, 2011, from http://www.sciencedirect.com.ezproxy.auckland.ac.nz/science/article/pii/S073805939800039X

Kohlberg, L. (1981). Moral stages and the idea of justice: Essays on moral development. New York: Harper \& Row.

Lee, R. (1995). Dangerous Fieldwork. London: Sage.

Lemon, A. (2004). Redressing school inequalities in the Eastern Cape, South Africa. Journal of Southern African Studies, 30(2), 269290. Retrieved December 10, 2009, from http://search.ebscohost.com/login.aspx?direct=true\&db=a2h\&AN=13621795\&site =ehost-live

Liebenberg, S. (2010). Socio-economic rights: Adjudication under a transformative constitution. Cape Town: Juta.

Lincoln, Y., \& Guba, E. (1985). Naturalistic Inquiry. Newbury Park, CA: Sage.

Mampane, R., \& Bouwer, C. (2011). The influence of township schools on the resilience of their learners. South African Journal of Education, 31(1), 114-126. Retrieved October 29, 2011, from http://www.ajol.info/index.php/saje/article/viewFile/63495/51338

Maxwell, J. (2005). Qualitative research design: An interpretive approach (2nd ed.). Thousand Oaks, CA: Sage.

Merriam, S. (1988). Case study research in education: A qualitative approach (1st ed.). San Francisco: Jossey-Bass.

Moloi, K. (2010). How can schools build learning organisations in difficult education contexts? South African Journal of Education, 30(4), 
621-633. Retrieved October 2, 2011, from http://www.sajournalofeducation.co.za/index.php/saje/article/viewFile/392/218

Morrison, K. (2002). School leadership and complexity theory. London: Routledge/Falmer.

Naong, M. (2007). The impact of the abolition of corporal punishment on teacher morale: 1994-2004. South African Journal of Education, 27(2), 283-300. Retrieved May 6, 2011, from http://www.ajol.info/index.php/saje/article/viewFile/44143/27658

Ngcobo, T., \& Tikly, L. (2010). Key dimensions of effective leadership for change: A focus on township and rural schools in South Africa. Educational Management Administration \& Leadership, 38(2), 202-228. Retrieved July 6, 2011, from http://ema.sagepub.com. ezproxy.auckland.ac.nz/content/38/2/202.full.pdf+html

Noddings, N. (2005). Caring in education. The encyclopedia of informal education, Retrieved November 17, 2010, from www.infed.org/biblio/noddings caring in education.htm

Ofoegbu, F. (2004). Teacher motivation: A factor for classroom effectiveness and school improvement in Nigeria. College Student Journal, 38(5), 81-89.

Pendlebury, S., \& Enslin, P. (2007). What kinds of people are we? Values education after apartheid. In D. Aspin \& J. Chapman (Eds.), Values education and lifelong learning. Dordrecht: Springer. Retrieved January 13, 2010, from http://www.springerlink.com .ezproxy.auckland.ac.nz/content/m51453572p081m72/fulltext.pdf

Piaget, J. (1932). The moral judgment of the child (M. Gabain, Trans.). London: Routledge \& Kegan Paul.

Robinson, V. (1993). Problem-based methodology: Research for the improvement of practice. Oxford: Pergamon Press.

Robinson, V., \& Lai, M. (2006). Practitioner research for educators: A guide to improving classrooms and schools. Thousand Oaks, CA: Corwin Press.

Ryle, G. (1972). Can virtue be taught? In R. Dearden, P. Hirst \& R. Peters (Eds.), Education and the development of reason. London: Routledge.

Sayed, Y. (2002). Democratising education in a decentralised system: South African policy and practice. Compare: A Journal of Comparative and International Education, 32(1), 35-46.

Smit, B. (2001). How primary school teachers experience education policy change in South Africa. Perspectives in Education, 19(3), 6783. Retrieved July 7, 2010, from http://137.215.9.22/bitstream/handle/2263/4379/Smit_How(2001).pdf?sequence=1

Snook, I. (2000). The ethical teacher. Palmerston North: Dunmore Press.

Snook, I. (2007). Values education in context. In D. Aspin \& J. Chapman (Eds.), Values education and lifelong learning. Dordrecht: Springer.

Solomons, I., \& Fataar, A. (2011). A conceptual exploration of values education in the context of schooling in South Africa. South African Journal of Education, 31(2), 224-232. Retrieved June 7, 2011, from http://www.ajol.info/index.php/saje/article/view File/66456/54179

Strelitz, L. (2005). Mixed reception : South African youth and their experience of global media (1st ed.). Pretoria: Unisa Press.

Swanepoel, C. (2008). The perceptions of teachers and school principals of each other's disposition towards teacher involvement in school reform. South African Journal of Education, 28(1), 39-51. Retrieved December 4, 2010, from http://www.scielo.org.za /pdf/saje/v28n1/v28n1a03.pdf

Thomas, D. (2006). A general inductive approach for analyzing qualitative evaluation data. American Journal of Evaluation, 27(2), 237246. Retrieved October 28, 2011, from http://aje.sagepub.com.ezproxy.auckland.ac.nz/content/27/2/237.full.pdf+html

Veugelers, W., \& Vedder, P. (2003). Values in teaching. Teachers and Teaching, 9(4), 377-389. Retrieved September 18, 2009, from http://www.tandfonline.com.ezproxy.auckland.ac.nz/doi/pdf/10.1080/1354060032000097262

Winton, S. (2010). Character development and critical democratic education in Ontario, Canada. Leadership and Policy in Schools, 9(2), 220-237. Retrieved July 7, 2011, from http://www.tandfonline.com.ezproxy.auckland.ac.nz/doi/pdf/10.1080/15700760903100758

Yin, R. (2003). Case study research: Design and methods. London: Sage. 